Note

\title{
PRACTICAL METHOD FOR GERMINATION OF Araucaria angustifolia (Bert.) O. Ktze. SEEDS
}

\author{
Milene Moreira-Souza ${ }^{1,2}$; Elke Jurandy Bran Nogueira Cardoso ${ }^{1,3 *}$ \\ ${ }^{I}$ USP/ESALQ - Depto. de Solos e Nutrição de Plantas - C.P. 9 - 13418-900 - Piracicaba, SP - Brasil. \\ ${ }^{2}$ CAPES scholar. \\ ${ }^{3} \mathrm{CNPq}$ scholar. \\ *Corresponding author <ejbncard@esalq.usp.br>
}

\begin{abstract}
The germination of seeds of Araucaria angustifolia (Brazilian Pine) is generally a slow and fastidious process that causes loss of many seeds because of the incidence of pathogens. The objective of this study was to evaluate whether seeds with cut edges present greater germination percentages or precocity when compared to untreated, normal seeds. The experimental design was completely randomized design with 100 pre-cut and 100 non-treated seeds. The experiment was installed twice, in 1998 and 1999, from fresh seeds. Pre-cut seed germination was higher: 92 and 95\% respectively, whereas whole seed germination was 60 and $64 \%$ in the two experiments. Seedlings originated from pre-cut seeds were uniform and showed less fungal contaminants.

Key words: Araucaria angustifolia, germination, seeds

\section{MÉTODO PRÁTICO PARA GERMINAÇÃO DE SEMENTES DE Araucaria angustifolia (Bert.) O. Ktze.}

\begin{abstract}
RESUMO: Sementes de Araucaria angustifolia (Bert.) O. Ktze. apresentam desuniformidade e lentidão na sua germinação, causando a perda de muitas sementes por ataque de patógenos e produzindo mudas desuniformes. O objetivo deste trabalho foi avaliar se sementes com as pontas cortadas antes da semeadura apresentam maior porcentagem e ou precocidade de germinação quando comparadas com sementes inteiras. O delineamento experimental foi inteiramente casualizado com dois tratamentos: sementes com as pontas cortadas e sementes inteiras, com 100 sementes em cada tratamento. O experimento foi realizado no ano de 1998 e repetido em 1999, empregando-se sementes recém colhidas. No primeiro e segundo ano a percentagem de germinação das sementes cortadas foi de $92 \%$ e $95 \%$ e nas inteiras foi de 60 e $64 \%$ respectivamente. As sementes com as pontas cortadas germinaram mais rapidamente do que as inteiras em ambos os experimentos. Plântulas provenientes de sementes cortadas tiveram seu desenvolvimento mais uniforme e não apresentaram contaminações por fungos.

Palavras-chave: Araucaria angustifolia, sementes, germinação
\end{abstract}

\section{INTRODUCTION}

Araucaria angustifolia (Bert.) O. Ktze., also known as Brazilian Pine and Parana Pine, is a typical species from the Brazilian subtropical forest, and occurs mainly in the states of Rio Grande do Sul, Santa Catarina, Paraná and São Paulo (Hueck, 1972). Isolated occurrences can be found in the states of Rio de Janeiro and Minas Gerais. This species used to be explored indiscriminately, because of its high economical value, related to the high quality of its wood.

One of the factors that make seedling production hard to achieve in this species is that seeds are recalcitrant, since they possess a high degree of humidity right after maturation and lose viability when dehydrated to levels that are still relatively high, between 12 and 35\% (Roberts, 1973).
Viability loss in these seeds occurs in a few months (Prange, 1963; Aquila \& Ferreira, 1984; Eira et al., 1994) and their use in forest plantings must take place in up to 45 days after dispersion (Vernalha et al., 1972).

Results from studies on the germination of forestry species show that scarification increases the percentage of germination in all studied species (Acuña \& Garwood, 1987). Several types of seed cuts are also utilized to provide a uniform and early germination. A survey in the available literature showed that many experiments have been carried out to improve seed germination in araucaria and, in some of them, several types of cuts were performed in the seeds (Ramos \& Bianchetti, 1990; Eira et al. 1991). By and large, such cuts favored seed germination (Aquila \& Ferreira, 1984; Eira et al. 1991). However, since these preconized cuts are too complex, their utilization for obtaining a large amount of arau- 
caria seedlings would become difficult. Therefore, a more simple and effective process is needed to solve this hindrance once and for all.

Considering that no practical recommendations exist concerning a suitable method for the germination of this species in the Regras para Análise de Sementes (Regulations for Seed Analysis) (Brasil, 1992), the objectives of this study were to evaluate the effect of cuts in araucaria seeds and to provide technical references for its large scale utilization.

\section{MATERIAL AND METHODS}

The araucaria seeds utilized in this experiment were collected on the ground around five randomly-chosen stock trees, in Campos do Jordão, SP, Brazil, (22 ${ }^{\circ} 41^{\prime}$ S and $\left.45^{\circ} 27^{\prime} \mathrm{W}\right)$. Two collections were taken, and the same stock trees were utilized (April 1998 and April 1999). The experiments were conducted in a greenhouse in Piracicaba, SP.

The seeds were placed in a container filled with water, and only seeds that sank were selected and then uniformized by size and divided into two lots (A and B), of 100 seeds each. Seeds in lot A were cut and those in lot B remained intact. All seeds were treated with sodium hypochlorite at $2 \%$ for 30 minutes and then rinsed in running water. The cut consisted in the removal, with a sharp cutter, of approximately $3 \mathrm{~mm}$ from the tip of each seed, without damaging the endosperm and the

A
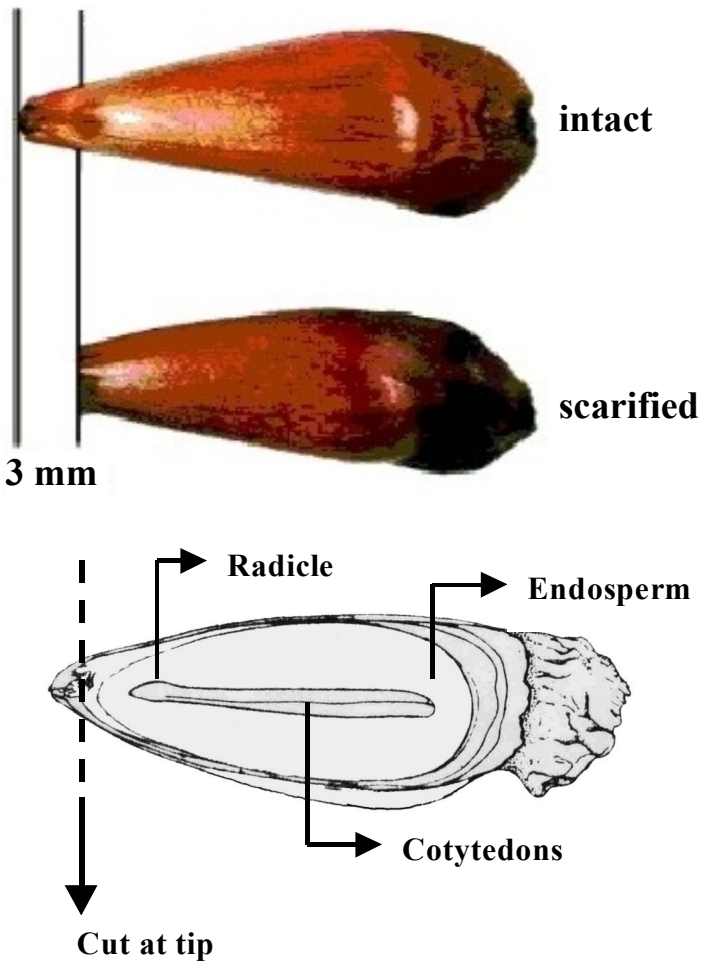

B Cut at tip

Figure 1 - (A and B) Aspect of cut at tip of Araucaria angustifolia seeds. radicle (Figure 1). Immediately after cutting, seeds were sown in 2 plastic trays (one for each treatment) at 10 $\mathrm{cm}$ depth, containing river sand that was washed and sterilized by autoclaving for 2 hours at $121^{\circ} \mathrm{C}$. Seeds were allowed to germinate in the horizontal position, covered by $1 \mathrm{~cm}$ of sand. After planting, the two lots were periodically irrigated as needed, and the same volume of water was consistently utilized for the two treatments up to two months after the installation of the experiment; number of germinated seeds was assessed every other week. The normal seedling criterion prescribed in the Regras para Análise de Sementes (Brasil, 1992) was adopted as an adequate standard to evaluate the germination test.

Results were evaluated statistically, and the test for proportion differences (Costa-Neto, 1977) was utilized. Comparisons between germination times for the two seed treatments and between the two years of experimentation were evaluated at $P=0.05$. The descriptor levels of $\mathrm{P}$ values for this test were calculated and the decision rule was to reject the $\mathrm{H}_{0}$ hypothesis when $P<0.05$.

\section{RESULTS AND DISCUSSION}

Differences were detected between the treatments in each time studied, i.e., the proportion of cut seeds that germinated was greater than the proportion of whole seeds in all studied times (Figure 2). The descriptor level of the $\mathrm{P}$ value in this test for comparison between treatments ranged from 0.000 to 0.006 and the null hypothesis was rejected. Therefore, the two treatments were different between themselves, at a high significance level.

However, when the two years were compared for the two treatments under consideration, no significant difference was detected, i.e., there were no differences between years within the same period in all times that were studied. In addition, the $\mathrm{P}$ value ranged from 0.389 to 0.869 , thus ensuring that there was no difference in behavior from one year to the next.

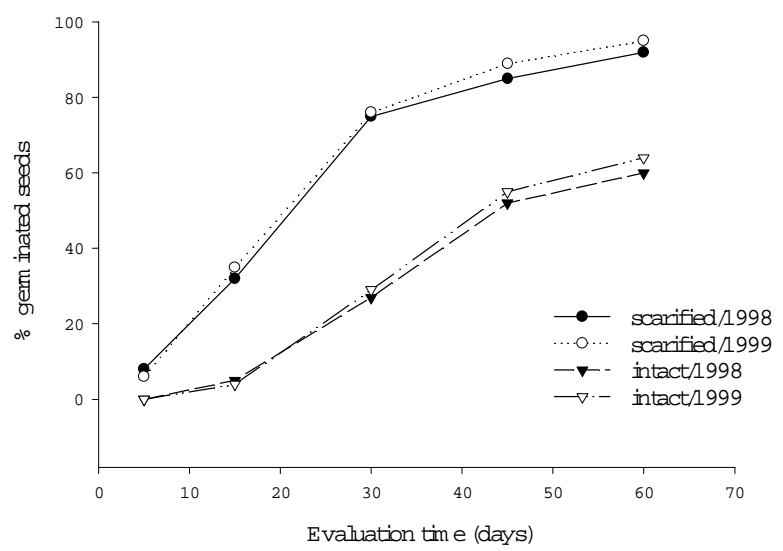

Figure 2 - Germination percentages of Araucaria angustifolia seeds in different evaluation periods. 
In the first year, there was $92 \%$ germination, with uniform seedling development in the lot where seed tips were sectioned. In lot $\mathrm{B}$, where seeds remained intact, germination was only $60 \%$ during this period and part of the seedlings were contaminated by fungi. In yet another study on the germination of araucaria seeds with and without seed cuts, Aquila et al. (1984) observed, at 60 days, $69 \%$ germination for scarified or cut seeds and $34 \%$ for whole seeds. The values found by Aquila et al. (1984), in spite of being a little lower in the two treatments with regard to ratios, are proportional to those obtained in the present study, and the cause could be related to the quality of the seed lot. Even though the germination percentage results are similar in the two studies, operational advantages were obtained in the present work because cutting was easy.

In 1999, lot A started to germinate five days after the installation of the experiment, while in lot B germination only started 13 days after sowing. By the end of 60 days, $95 \%$ of the treated (cut) seeds had germinated, while only $64 \%$ of the whole seeds germinated (Figure 2). Again, seedlings from cut seeds were normal, according to the rules for seed analysis (Brasil, 1992; Rodrigues, 1988). These seedlings showed vigorous development of roots and shoots, while many of those from intact seeds showed a stunted or contorted root system, which caused death to many of them. The phytosanitary conditions in seedlings from lot A were also excellent, whereas serious contamination occurred in the other by opportunistic fungi that managed to colonize the roots of seedlings resulting from intact seeds. The fact that intact seeds always obtain lower germination rates can be explained by the mechanical impediment exerted by the wrappers, preventing seed expansion and making imbibition difficult (Ferreira \& Handro, 1979; Cunha et al., 1991). Whole seeds take longer to germinate, and the epicotyl only develops when it is totally free from the endosperm, i.e., when the cotyledons are sufficiently dilated, to the point where the embryo axis is completely external relative to the seed (Doni Filho et al., 1985).

Similar results were found in other studies with $A$. angustifolia, conducted in forest and field soils, to test seed viability and humidity content on germination, by means of different types of cuts, including transverse and longitudinal cuts (Eira et al., 1991; Aquila \& Ferreira, 1984; Doni Filho et al., 1985; Ramos \& Bianchetti, 1990). Ferreira (1977), utilizing paper as substrate, and Cardemil \& Reinero (1982), utilizing vermiculite for germination of Araucaria araucana seeds, also reported that different types of cuts induced better germination. All these studies were conducted under settings that were different from the present work, since they induced germination by means of much more complex cutting processes or even by the complete removal of the integument. These procedures are labor-intensive and could impede the pro- duction of large amounts of seedlings, as it is necessary in nursery operations aimed at reforestation. The method we describe, however, consists of a small cut at the tip of the seed, which is simple to perform, resulting in early and uniform araucaria seed germination.

\section{ACKNOWLEDGEMENTS}

The first author gratefully acknowledges Coordenadoria de Aperfeiçoamento de Pessoal de Nível Superior (CAPES) for a fellowship grant. We also wish to acknowledge the State Park of Campos do Jordão and the Secretariat of the Enviromment of São Paulo State for authorizing the collection of seeds (Process no. 40405/ 98 COTEC 079/98). We wish to express thanks to laboratory technicians Denise Mescolotti and Luís Fernando Baldesin for their help during the experiment.

\section{REFERENCES}

ACUÑA, P.I.; GARWOOD, N. Efecto de la luz y de la escarificación en la germinación de las semillas de cinco especies de árboles tropicales secundarios. Revista de Biologia Tropical, v.35, p.203-207, 1987.

AQUILA, M.E.A.; FERREIRA, A.G. Germinação de sementes escarificadas de Araucaria angustifolia em solo. Ciência e Cultura, v.36, p.15831589, 1984.

BRASIL. Ministério da Agricultura e Reforma Agrária. Regras para análise de sementes. Brasília: LAVARV/SNAD/MA, 1992. 365p.

CARDEMIL, L.; REINERO, A. Changes of Araucaria araucana seed reserves during germination and early seedling growth. Canadian Journal of Botany, v.60, p.1629-1638, 1982.

COSTA-NETO, P.L.O. Estatística. São Paulo: Edgard Blücher, 1977. 264p.

CUNHA, R.; EIRA, M.T.S.; SALOMÃO, A.N. Metodologia para determinação do grau de umidade de sementes de Araucaria angustifolia (Bert.) O. Ktze. Informativo ABRATES, v.1, p.87, 1991.

DONI FILHO, L.; AMARAL, L.; CERVI, P.H. Métodos para testar o poder germinativo das sementes de Araucaria angustifolia (Bert.) O. Ktze. Revista Brasileira de Sementes, v.7, p.113-123, 1985.

EIRA, M.S.T.; CUNHA, R.; SALOMÃO, A.N. Efeito do tegumento sobre a germinação de sementes de Araucaria angustifolia (Bert.) O. Ktze. Informativo ABRATES, v.1, p.77, 1991.

EIRA, M.S.T.; SALOMÃO, A.N.; CUNHA, R.; CARRARA, D.K.; MELLO, C.M.C. Efeito do teor de água sobre a germinação de sementes de Araucaria angustifolia (Bert.) O. Ktze. - ARAUCARIACEAE. Revista Brasileira de Sementes, v.16, p.71-75, 1994.

FERREIRA, A.G. Araucaria angustifolia (Bert.) O. Ktze.: germinação da semente e desenvolvimento da plântula. São Paulo: USP/IB, 1977. 123p. (Tese - Doutorado)

FERREIRA, A.G.; HANDRO, W. Aspects of seed germination in Araucaria angustifolia (Bert.) O. Ktze. Revista Brasileira de Botânica, v.2, p.713, 1979.

HUECK, K. As florestas da América do Sul. São Paulo. Polígono. 1972, 466p.

PRANGE, P.W. Estudo de conservação do poder germinativo das sementes de Araucaria angustifolia (Bert). O. Ktze. Anuário Brasileiro de Economia Florestal, v.16, p.43-53, 1963.

RAMOS, A.; BIANCHETTI, A. Metodologia para determinação do teor de umidade de sementes de Araucaria angustifolia (Bert). O. Ktze. Revista Brasileira de Sementes, v.12, p.9-16, 1990.

ROBERTS, E.H. Predicting the storage life of seeds. Seed Science and Technology, v.1, p.499-514, 1973.

RODRIGUES, F.C.M.P.; VIEIRA, D.J. Manual de sementes florestais: teste de germinação. Campinas: Fundação Cargill, 1988. cap.8, p.70-86.

VERNALHA, M.M.; LEAL, J.; GABARDO, L.C.; ROCHA, M.A.L.; SILVA, R.P. Considerações sobre a semente de Araucaria angustifolia (Bert) O. Ktze. Acta Biológica Paranaense, v.1, p.39-96, 1972.

Received May 17, 2002 